\title{
Tanggung Jawab Notaris Dan Kekuatan Hukum Dalam Pembuatan Akta Konsen Roya
}

\section{Primistha Elsyanita Devi}

Magister Kenotariatan Fakultas Hukum Universitas Islam Indonesia Yogyakarta Indonesia Jln. Cik Di Tiro No. 1 Yogyakarta Indonesia primistha@gmail.com

\begin{tabular}{|c|c|}
\hline $\begin{array}{l}\text { Key Word: Roya's } \\
\text { Consensus Deed, } \\
\text { Partij Acta, Notary's } \\
\text { responsibility }\end{array}$ & $\begin{array}{l}\text { Abstract } \\
\text { This study aims to examine and analyze the responsibilities of a notary in the roya } \\
\text { consent deed and the legal force of the roya consent deed. This research is classified } \\
\text { as normative juridical by using a statute approach, and conceptual approach. Data } \\
\text { collection techniques used are interviews, literature studies and documents. The } \\
\text { results of this study concluded that the agreement deed was made based on formal } \\
\text { information and evidence submitted by the appearers. The agreement deed is a } \\
\text { notarial deed in the form of a partij acta with perfect power as the legal force of the } \\
\text { authentic deed itself. Notaries are not responsible for the content of actions made } \\
\text { based on the will of the parties. The material truth of the contents of the deed comes } \\
\text { from what was submitted by the parties. The roya consent deed is a notarial deed } \\
\text { that meets the requirements as a substitute for a lost mortgage certificate, which } \\
\text { works as a condition for roya registration or deletion of mortgage. This research was } \\
\text { conducted because in practice there is still the inclusion of documents or } \\
\text { information that is not true/false by the parties so that the Notary in making the } \\
\text { agreement deed must get protection }\end{array}$ \\
\hline
\end{tabular}

\begin{tabular}{l}
\hline Kata-kata Kunci: \\
Akta Konsen Roya, \\
Partij Acta, \\
Tanggung Jawab \\
Notaris
\end{tabular}

\section{Abstrak}

Penelitian ini bertujuan untuk mengkaji dan menganalisis tanggung jawab notaris dalam pembuatan akta konsen roya dan kekuatan hukum akta

Tanggung Jawab konsen roya. Penelitian ini tergolong yuridis normatif dengan menggunakan pendekatan perundang-undangan, dan pendekatan konsep. Teknik pengumpulan data yang digunakan adalah wawancara, studi pustaka dan dokumen. Hasil dari penelitian ini menyimpulkan bahwa akta konsen roya dibuat berdasarkan keterangan dan bukti formal yang disampaikan oleh penghadap. Akta konsen roya merupakan akta notaris yang berbentuk partij acta dengan kekuatan yang sempurna sebagaimana kekuatan hukum dari akta autentik itu sendiri. Notaris tidak bertanggung jawab terhadap isi akta yang dibuat berdasarkan kehendak para pihak. Kebenaran materiil dari isi akta berasal dari yang disampaikan para pihak. Akta konsen roya merupakan akta notariil yang mempunyai kedudukan sebagai syarat pengganti sertifikat hak tanggungan yang hilang, yang berfungsi sebagai syarat pendaftaran roya atau pencoretan hak tanggungan. Penelitian ini dilakukan karena pada praktek masih terjadi adanya penyertaan dokumen atau keterangan tidak benar/palsu yang dilakukan para pihak sehingga Notaris dalam pembuatan akta konsen roya harus mendapatkan perlindungan

\section{Pendahuluan}

Pasal 22 Undang-Undang Nomor 4 Tahun 1996 tentang Hak Tanggungan Atas Tanah Beserta Benda-benda yang Berkaitan dengan Tanah yang selanjutnya disebut UUHT mengatur tentang roya hak tanggungan. Pasal tersebut menyatakan bahwa roya merupakan pencoretan hak tanggungan pada buku hak atas tanah dan sertifikatnya. 
Roya dapat dilakukan apabila seluruh persyaratan telah terpenuhi. Syarat melakukan roya diantaranya adalah harus adanya formulir permohonan yang sudah diisi dan ditandatangani pemohon atau kuasanya di atas materai cukup, surat kuasa apabila dikuasakan, fotokopi identitas pemohon (Kartu Tanda Penduduk, Kartu Keluarga) dan kuasa apabila dikuasakan yang telah dicocokkan dengan aslinya oleh petugas loket, fotokopi akta pendirian dan pengesahan badan hukum yang telah dicocokkan dengan aslinya oleh petugas loket bagi badan hukum, sertifikat tanah dan sertifikat hak tanggungan dan/atau konsen roya jika sertifikat hak tanggungan hilang, surat roya/keterangan lunas/pelunasan hutang dari kreditur, fotokopi Kartu Tanda Penduduk pemberi hak tanggungan (debitur), penerima hak tanggungan (kreditur) dan/atau kuasanya yang telah dicocokkan dengan aslinya oleh petugas loket. ${ }^{1}$

Akta konsen roya adalah akta autentik yang dibuat di hadapan notaris atas permintaan atau keinginan dari kreditur karena hilangnya sertifikat hak tanggungan yang berada dalam kekuasaan debitur. Akta tersebut berisi pernyataan telah hilangnya sertifikat hak tanggungan yang didukung dengan surat kehilangan dari pihak kepolisian. Akta konsen roya tidak diatur secara khusus tetapi berperan sebagai hukum kebiasaan (living law). ${ }^{2}$

Akta konsen roya adalah sebuah akta autentik yang berbentuk partij acta atau akta para pihak yang berarti isinya berdasarkan keterangan dari para pihak. Partij acta dibuat berdasarkan keterangan atau perbuatan pihak yang menghadap Notaris, selanjutnya keterangan atau perbuatan tersebut akan dikonstatir oleh Notaris untuk dibuatkan akta ${ }^{3}$.

Dalam implementasinya terdapat kesalahpahaman atas pertanggung jawaban notaris terhadap akta konsen roya. Notaris diapandang memiliki tanggungjawab atas akta tersebut pada awal dan akhir akta, termasuk pula isi akta yang pada hakikatnya merupakan pernyataan dari para pihak. Oleh karena itu peneliti tertarik untuk meneliti lebih lanjut melalui penelitian yang berjudul "Tanggung Jawab Notaris dan Kekuatan Hukum dalam Pembuatan Akta Konsen Roya".

\section{Rumusan Masalah}

1. Bagaimana tanggung jawab Notaris atas pembuatan akta konsen roya?

2. Bagaimana kekuatan hukum akta konsen roya?

\section{Tujuan Penelitian}

1. Untuk mengkaji dan menganalisis tanggung jawab Notaris atas pembuatan akta konsen roya.

2. Untuk mengkaji dan menganalisis kekuatan hukum akta konsen roya.

\footnotetext{
1 Anonim, Hapusnya Hak Tanggungan/Roya: https://www.atrbpn.go.id/Publikasi/StandarProsedur/moduleId/122856/itemName/Roya/controller/Item/action/Detail, (Diakses pada 06 Agustus 2019).

${ }^{2}$ Arindi Ayudia Darmayanti, Kekuatan Mengikat Akta Konsen Roya yang Dibuat oleh Notaris, Tesis Magister Kenotariatan, Universitas Udayana, Denpasar, 2016, hlm. 2.

${ }^{3}$ F. Eka. Sumarningsih, Peraturan Jabatan Notaris, Diktat Kuliah Program Studi Notariat, Fakultas Hukum, Universitas Dipenogoro, Semarang, 2001, hlm. 7.
} 


\section{Metode Penelitian}

Jenis penelitian ini adalah yuridis normatif, yaitu penelitian yang difokuskan untuk mengkaji penerapan kaidah-kaidah atau norma-norma dalam hukum positif. ${ }^{4}$ Objek penelitian yaitu sertifikat hak tanggungan, akta konsen roya yang dibuat oleh notaris berdasarkan kehendak para pihak dan kekuatan hukum akta konsen roya yang dibuat oleh notaris. Pendekatan masalah yang digunakan dalam penelitian ini adalah pendekatan undang-uundang (statute approach) dan pendekatan konsep (conseptual approach). Kajian literatur dilakukan untuk mendapatkan data sekunder yang relevan dengan penelitian ini, meliputi berbagai publikasi buku-buku teks, skripsi, tesis, kamuskamus hukum, jurnal-jurnal hukum, dan komentar-komentar hukum atas pengadilan ${ }^{5}$. Teknik pengumpulan data yang digunakan peneliti adalah studi dokumen dan wawancara.

\section{Hasil Penelitian dan Pembahasan}

\section{Analisis Tanggung Jawab Notaris atas Pembuatan Akta Konsen Roya}

Akta Notaris dikatakan sebagai akta autentik selama pembuatan akta tersebut memenuhi unsur yang ada dalam Pasal 15 Ayat (1) Undang-Undang No 30 Tahun 2004 tentang Jabatan Notaris sebagaimana diubah dengan Undang-Undang Nomor 2 Tahun 2014 (sleanjutnya disebut dengan UUJN). Suatu akta notaris juga harus memenuhi unsur dari syarat sahnya suatu perjanjian sebagaimana yang ada dalam Pasal 1320 KUHPerdata yaitu: a) sepakat mereka yang mengikatkan diri; b) kecakapan membuat suatu perjanjian; c) suatu hal tertentu dan; d) kausa yang halal.

Adanya syarat perjanjian dalam Pasal 1320 memiliki konsekuensi bilamana tidak terpenuhi salah satu syarat maka dapat mengakibatkan perjanjian cacat hukum. Tidak terpenuhinya syarat yang pertama dan kedua sebagai syarat subjektif, maka suatu perjanjian berakibat dapat dibatalkan. Sedangkan tidak terpenuhinya syarat ketiga dan keempat sebagai syarat objektif, mengakibatkan suatu perjanjian akan batal demi hukum. 6

Partij acta memiliki kekuatan pembuktian sempurna bagi pihak-pihak yang bersangkutan, termasuk para ahli warisnya serta orang-orang yang menerima hak dari mereka tersebut. Partij acta adalah suatu bentuk akta yang bersifat fleksibel karena dalam akta tersebut, isi yang diperjanjikan adalah kehendak atau keinginan dari para pihak sendiri. Dikarenakan sifat partij acta yang fleksibel, maka akta tersebut sering digunakan sebagai alternatif hukum bagi masyarakat secara umum, salah satunya yaitu akta konsen roya.

Banyak masalah mengenai roya yang terjadi, diantaranya yaitu setelah terjadinya pelunasan, banyak yang tidak langsung melaksanakan pencoretan atau roya sehingga ini

\footnotetext{
${ }^{4}$ Johnny Ibrahim, Teori dan Metodologi Penelitian Hukum Normatif, Bayumedia Publishing, Malang, 2006, hlm. 295.

${ }^{5}$ Marzuki, Metodologi Riset, Penerbit BPFE-UII, Yogyakarta, 2002, hlm. 95.

${ }^{6}$ M. Edwin Azhari, dan Djauhari, "Tanggung Jawab Notaris dalam Pembuatan Akta Perjanjian Nominee dalam Kaitannya dengan Kepemilikan Tanah oleh Warga Negara Asing di Lombok”, Jurnal Akta Vol. 5 No 1 Maret 2018, Semarang: UNISSULA, 2018, hlm. 48.
} 
sering menjadi masalah. Disinilah peran Notaris diharapkan memberikan edukasi dan penyuluhan hukum kepada klien jika masih ada tanggungan maka segera didaftarkan roya. ${ }^{7}$

Muhammad Munakam, sebagai Kepala Sub. Seksi Pendaftaran Hak Atas Tanah, Seksi Hubungan Hukum Pertanahan Kantor Pertanahan Kota Yogyakarta menyatakan bahwa akta konsen roya merupakan solusi dari kantor pertanahan pada saat sertifikat hak tanggungan hilang untuk digunakan memenuhi kelengkapan prosedur pelaksanaan roya. Dasar hukum akta konsen roya sendiri berasal dari Peraturan Kepala Badan Nomor 1 Tahun 2010 tentang Standar Pelayanan dan Pengaturan Pertanahan. Pada saat telah terjadi pelunasan tetapi sertifikat hak tanggungan dan akta pemberian hak tanggungan yang telah dijahit menjadi satu dinyatakan hilang maka langkah yang diambil yaitu menghadap kepada Notaris untuk dibuatkan akta konsen roya. Setelah akta konsen roya jadi, maka pihak kantor pertanahan akan melakukan cek. Cek tersebut mengenai materi isi dari akta konsen roya tersebut apakah sama dengan buku tanah milik kantor pertanahan.

Keberadaan akta konsen roya didasarkan pada kebiasaan. Syarat konsen roya yaitu surat kehilangan dari kepolisian, sertifikat asli, surat pengantar roya dari kreditur, surat keterangan lunas dari kreditur atau pemegang hak tanggungan yang tercatat dalam sertifikat hak ${ }^{8}$. Atas kebenaran bukti-bukti yang disampaikan penghadap tersebut bukanlah tanggung jawab Notaris. Hal ini karena sifat dari akta konsen roya yang merupakan partij acta.

Kebenaran atas bukti-bukti yang telah disampaikan oleh para penghadap bukanlah tanggung jawab Notaris. Akta konsen roya sebagai akta pihak (partij acta) berisikan pernyataan para pihak, dalam hal mana tanggung jawab Notaris tersebut dalam pembuatannya hanya sebatas awal dan akhir akta yang dibuat, tidak termasuk pada isi akta yang berisikan hasil dari Notaris mengkonstatir pernyataan atau penyampaian dari para pihak ${ }^{9}$.

Noviana Ariviani mengatakan,10 bahwa tanggung jawab Notaris hanya sebatas mengkonstantir kepentingan para pihak yang terlibat dalam akta tersebut dan memastikan bahwa akta tersebut telah memenuhi syarat formil yang ditentukan oleh undang-undang. Atas segala keterangan, identitas maupun dokumen yang diberikan kepada Notaris bukan merupakan tanggung jawab Notaris untuk melakukan pengecekan hingga ke ranah materiil, karena Notaris bekerja pada ranah hukum formil. Apabila kemudian hari akta yang diterbitkan oleh Notaris terdapat keterangan palsu dan menimbulkan kerugian, maka tanggung jawab tidak bisa dibebankan pada Notaris karena telah menjalankan jabatannya sesuai peraturan yang berlaku. Notaris tidak bisa

7 Wawancara dengan M. Munakam, selaku Kepala Sub. Seksi Pendaftaran Hak Atas Tanah, Seksi Hubungan Hukum Pertanahan Kantah Kota Yogyakarta pada 11 Februari 2020.

${ }^{8}$ Wawancara Mulyoto, selaku Dosen Magister Kenotariatan Fakultas Hukum Universitas Islam Indonesia pada 29 Juli 2019.

9 Ignasia Novika Roseno, "Kewenangan Notaris dalam Pembuatan Akta Konsen Roya", Tesis, Surabaya: Universitas Airlangga, 2011, hlm. 1.

${ }^{10}$ Ibid. 
dituntut wanprestasi karena bukan merupakan hubungan kontraktual karena isi akta merupakan inisiatif penghadap.

Akibat hukum dari suatu akta autentik melekat sepanjang akta tersebut tidak diubah atau dibatalkan oleh para pihak yang mengikatkan diri dalam suatu akta notaris. Yakni walaupun notaris yang membuat akta telah berakhir masa jabatannya, akan tetapi akta autentik notaris yang dibuat tersebut tetap berlaku sebagai Undang-Undang bagi para pihak atau mereka yang telah membuatnya, sedangkan bagi notaris, dalam hal ini hanya bertanggung jawab terhadap formil akta yang telah dibuatnya tersebut, bukan terkait pada isi dari akta tersebut. Oleh karena itu, Notaris dalam membuat akta harus tetap memenuhi standar prosedur yang berlaku, sehingga pertanggungjawaban Notaris terhadap akta yang dibuatnya harus tetap melekat seumur hidup pada diri Notaris tersebut. ${ }^{11}$

\section{Kekuatan Hukum Akta Konsen Roya}

Akta konsen roya identik dengan akta pernyataan dan kuasa untuk roya yang berisikan tentang suatu pernyataan dari pihak kreditur yang berisikan keterangan bahwa sertifikat hak tanggungan tersebut telah hilang. Keterangan tersebut berisi bahwa utang debitur telah dibayar lunas, dan pihak kreditur menyetujui serta telah memberikan kuasa untuk melaksanakan penghapusan hak tanggungan. ${ }^{12}$

Akta konsen roya dilihat dari segi normatif, secara spesifik tidak diatur dalam peraturan perundang-undangan atau aturan manapun. ${ }^{13}$ Akta konsen roya yaitu akta Notaris, memiliki kedudukan sebagai pengganti dari sertifikat hak tanggungan yang telah hilang, dan berfungsi sebagai syarat dari pendaftaran roya atau pencoretan hak tanggungan. Akta konsen roya dalam sebuah praktek pendaftaran tanah, memiliki kedudukan sebagai sebuah syarat dari pendaftaran hak atas tanah yang menggantikan sertifikat hak tanggungan yang hilang. Berdasarkan UUJN dan Kode Etik Notaris, Notaris dalam menyusun suatu akta konsen roya, bertanggung jawab secara hukum perdata dan hukum administrasi jika akta konsen roya yang dibuat Notaris tersbut berisikan unsur adanya perbuatan melanggar hokum. Oleh karena itu, akta tersebut akan kehilangan keautentikan sehingga berubah menjadi akta di bawah tangan sesuai dengan isi ketentuan dalam Pasal 41 UUJN14.

Bentuk partij acta pada prinsipnya sama dengan bentuk akta yang terdapat pada Pasal 38 UUJN. Prosedur dan ketentuan Notaris dalam membuat akta yaitu melakukan pengenalan identitas terhadap penghadap berdasarkan identitasnya yang diperlihatkan kehadapan Notaris, selanjutnya Notaris menanyakan kemudian mendengarkan dan mencermati keinginan atau kehendak para pihak, dan memberikan saran serta membentuk kerangka akta untuk memenuhi keinginan dari para pihak tersebut,

11 Herianto Sinaga, Tanggung Jawab Werda Notaris terhadap Akta yang Dibuatnya, https://media.neliti.com/media/publications/14062-ID-tanggungjawab-werda-notaris-terhadap-akta-yangdibuatnya.pdf, hlm. 9, Diakses pada 05 Desember 2019.

12 David Setiawan, dkk, "Kedudukan Hukum Akta Pernyataan Dan Kuasa Untuk Roya (Konsen Roya) Dalam Proses Lelang”, Lambung Mangkurat Law, Journal Vol 3 Issue 2, September 2018, hlm. 270-271.

13 Rudi Indrajaya dan Ika Ikmassari, Akta Izin Roya Hak Tanggungan sebagai Pengganti Sertifikat Hak Tanggungan yang Hilang, Visimedia, Jakarta, 2016, hlm 3.

14 Arindi Ayudia Darmayanti, Op. Cit., hlm. 3. 
kemudian Notaris memenuhi segala teknik administratif pembuatan akta Notaris seperti pembacaan, penandatanganan, memberikan salinan dan pemberkasan untuk minuta dan melakukan kewajiban lain yang berkaitan dengan pelaksanaan tugas jabatan Notaris.

Akta konsen roya yang telah dibuat di hadapan Notaris sebagai pengganti sertifikat hak tanggungan untuk melengkapi syarat administatif dari penghapusan atau pencoretan hak tanggungan pada kantor pertanahan. ${ }^{15}$ Susunan proses dalam pembuatan akta konsen roya hampir menyerupai tahapan proses dari pembuatan akta lainnya, perbedaannya yakni pada akta konsen roya menggunakan tambahan surat kehilangan dari kepolisian dan surat roya dari bank. Kedudukan dari suatu akta konsen roya hanya sebagai syarat pengganti sertifikat hak tanggungan yang hilang tidak digunakan untuk eksekusi. Kedudukan akta konsen roya tidak dapat disamakan dengan sertifikat hak tanggungan yang bersifat eksekutorial. ${ }^{16}$ Sertifikat hak tanggungan yang telah hilang tidak bisa dikeluarkan sertifikat pengganti yang tidak sama dengan sertifikat hak atas tanah yang apabila telah hilang maka dapat dikeluarkan sertifikat pengganti. Hilangnya sertifikat hak tanggungan pada hakikatnya akan merugikan kedua belah pihak, baik kreditur maupun debitur.

Akta konsen roya yang merupakan akta notaris sebagai akta autentik memiliki fungsi formil (formalitas causa) dan juga dapat berfungsi sebagai alat bukti (probationis causa). Akta autentik mempunyai tiga kekuatan pembuktian, yaitu kekuatan pembuktian lahiriah, kekuatan pembuktian formil, dan kekuatan pembuktian materiil.

a. Kekuatan Pembuktian Lahiriah

Kekuatan pembuktian lahiriah adalah kemampuan dari suatu akta itu sendiri untuk terbukti sebagai akta autentik. Berdasarkan Pasal 1875 KUHPerdata, kekuatan pembuktian lahiriah tidak terdapat pada akta di bawah tangan. Akta di bawah tangan hanya berlaku sah kepada siapa akta itu digunakan dan pihak yang disebutkan dalam akta tersebut menyatakan kebenaran tanda tangan miliknya. Akta autentik akan membuktikan sendiri keabsahannya. Hal tersebut berarti suatu akta yang memenuhi syarat dan memiliki bentuk seperti akta autentik, maka akta tersebut berlaku dan dianggap seperti aslinya (acta publika probant seseipsa) hingga ada pembuktian sebaliknya. Persoalan kekuatan pembuktian lahiriah akta autentik hanyalah mengenai keaslian tanda tangan dari pejabat yang berwenang dalam akta. Menurut Pasal 138 Rib/164 RDS (Pasal 148 KUHPerdata) pembuktian sebaliknya yang diajukan oleh pihak lawan hanya diperbolehkan dengan menggunakan surat, saksi-saksi, serta ahli. Kekuatan pembuktian lahiriah dari sebuah akta autentik adalah pembuktian yang tidak kurang (lengkap), berlaku terhadap setiap orang, serta tidak terbatas pada para pihak saja. Kekuatan pembuktian lahiriah sebagai alat bukti adalah sebuah keistimewaan dari akta autentik (akta pejabat maupun akta para pihak.

b. Kekuatan Pembuktian Formal

Akta autentik yang memiliki kekuatan pembuktian formal berarti terjaminnya kebenaran dan kepastian tanggal akta, kebenaran tanda tangan yang terdapat dalam akta, identitas dari orang-orang yang hadir (comparaten) dan juga tempat dimana akta

15 Ibid.

${ }^{16}$ Ibid., hlm. 1. 
itu dibuat. Tidak mengurangi pembuktian sebaliknya, maka pembuktian formal akta autentik merupakan pembuktian lengkap, dimana kekuatan pembuktian akta pejabat maupun akta para pihak adalah sama, artinya bahwa keterangan pejabat yang terdapat dalam kedua golongan akta maupun keterangan para pihak dalam akta tersebut memiliki kekuatan pembuktian formal dan berlaku terhadap setiap orang.

c. Kekuatan Pembuktian Materiil

Kekuatan pembuktian materiil akta autentik merupakan suatu kepastian bahwa para pihak tidak hanya sekedar menghadap dan menerangkan kepada Notaris akan tetapi juga membuktikan bahwa mereka juga telah melakukan seperti apa yang tercantum dalam materi akta. Kekuatan pembuktian akta notaris menurut Pasal 1870, 1871, dan Pasal 1875 KUHPerdata memberikan pembuktian yang sempurna dan mengikat tentang kebenaran yang terdapat dalam akta bagi para pihak yang bersangkutan, ahli waris serta penerima hak dengan pengecualian bilamana yang tercantum dalam akta hanya sekedar penuturan belaka atau tidak memiliki hubungan langsung dengan akta.

Kekuatan hukum partij acta di hadapan hukum mempunyai kekuatan yang sempurna, hal tersebut dikarenakan adanya keistimewaan dari suatu akta autentik yang terdapat pada kekuatan pembuktiannya. Akta autentik memberikan para pihak beserta ahli warisnya atau orang-orang yang mendapat hak darinya bukti yang sempurna. Akta autentik mempunyai kekuatan pembuktian sedemikian rupa yang dianggap telah melekat pada akta itu sendiri, dimana akta autentik tersebut merupakan suatu bukti yang mengikat dikarenakan apa yang telah tertulis dalam akta tersebut harus dianggap benar adanya dan dipercaya oleh hakim. Akta autentik juga memiliki kekuatan pembuktian yang sempurna karena tidak memerlukan penambahan alat bukti lainnya dengan kata lain akta autentik memiliki kekuatan pembuktian secara lahiriah, formal dan materiil. Akta notaris sebagai akta autentik memiliki kekuatan pembuktian lahiriah, formal dan materiil jika akta notaris tersebut disusun menurut ketentuan yang berlaku, maka akta tersebut akan mengikat para pihak sebagai akta autentik dan termasuk didalamnya pengadilan yang harus menerima akta notaris sebagai alat bukti yang sempurna.

\section{Penutup}

\section{Kesimpulan}

Akta konsen roya merupakan akta para pihak (partij acta) yang mempunyai sifat fleksibel yang dapat digunakan sebagai solusi hukum bagi permasalahan yang ada. Akta konsen roya dibuat berdasarkan keterangan dan bukti formal yang disampaikan oleh penghadap. Notaris tidak bertanggung jawab terhadap isi akta yang dibuat berdasarkan kehendak para pihak. Notaris hanya menuangkan kehendak para pihak dalam bentuk akta autentik sehingga Notaris tidak akan bertanggung jawab secara materiil. Tanggung jawab yang dimiliki oleh Notaris memiliki prinsip tanggung jawab berdasarkan pada kelalaian, kesengajaan, kesalahan (based on fault of liability). Notaris bertanggung jawab atas akta yang dibuatnya jika dalam pembuatan akta tersebut adanya unsur kelalaian, kesengajaan dan kesalahan yang diperbuat oleh Notaris yang tidak sesuai dengan Undang-Undang yang berlaku. Perlindungan hukum bagi Notaris berdasarkan pada Pasal 15 UUJN, yakni Notaris 
berwenang untuk menyusun akta sesuai kehendak penghadap (partij acta) sepanjang mengikuti aturan dan tidak bertentangan dengan hukum.

Akta Konsen Roya merupakan Akta Notaris yang berbentuk partij acta. Kekuatan hukum partij acta di hadapan hukum yaitu mempunyai kekuatan yang sempurna sebagaimana kekuatan hukum dari akta autentik itu sendiri. Kebenaran materiil dari isi akta berasal dari yang disampaikan para pihak. Akta konsen roya yaitu akta notariil yang memiliki kedudukan sebagai suatu syarat pengganti sertifikat hak tanggungan yang telah hilang, yang digunakan sebagai syarat dalam pendaftaran roya atau pencoretan hak tanggungan.

\section{Saran}

1. Perlu adanya batas yang lebih jelas tanggung jawab Notaris dalam pembuatan akta baik relaas acta maupun partij acta agar perlindungan hukum Notaris terjamin dalam menjaga keprofesionalitasannya.

2. Notaris harus lebih teliti dan memiliki sifat kehati-hatian dalam menerima dokumen hukum yang akan menjadi bagian dari syarat dalam pembuatan akta. Hal ini agar menghindari maraknya pemalsuan dokumen yang dapat disalah gunakan sehingga dapat menimbulkan kerugian bagi Notaris sendiri dan para pihak.

\section{Daftar Pustaka}

\section{Buku}

Ibrahim, Johnny, Teori dan Metodologi Penelitian Hukum Normatif, Malang: Bayumedia Publishing, 2006.

Indrajaya, Rudi dan Ika Ikmassari, Akta Izin Roya Hak Tanggungan sebagai Pengganti Sertifikat Hak Tanggungan yang Hilang, Jakarta: Visimedia, 2016.

Marzuki, Metodologi Riset,: Penerbit BPFE-UII, Yogyakarta, 2002.

Sumarningsih, F. Eka., Peraturan Jabatan Notaris, Semarang: Diktat Kuliah Program Studi Notariat, Semarang: Fakultas HukumUniversitas Dipenogoro, 2001.

\section{Jurnal, Tesis, Disertasi}

M. Edwin Azhari dan Djauhari, "Tanggung Jawab Notaris dalam Pembuatan Akta Perjanjian Nominee dalam Kaitannya dengan Kepemilikan Tanah oleh Warga Negara Asing di Lombok", Jurnal Akta Vol. 5 No 1 Maret 2018, Semarang: UNISSULA.

Ignasia Novika Roseno, "Kewenangan Notaris dalam Pembuatan Akta Konsen Roya", Tesis, Surabaya: Universitas Airlangga, 2011.

David Setiawan, dkk, "Kedudukan Hukum Akta Pernyataan Dan Kuasa Untuk Roya (Konsen Roya) Dalam Proses Lelang", Lambung Mangkurat Law Journal, Vol 3 Issue 2, September 2018.

\section{Wawancara}

Wawancara oleh M. Munakam selaku Kepala Sub. Seksi Pendaftaran Hak Atas Tanah, Seksi Hubungan Hukum Pertanahan Kantah Kota Yogyakarta pada tanggal 11 Februari 2020. 
Wawancara oleh Mulyoto, selaku Dosen Magister Kenotariatan Fakultas Hukum Universitas Islam Indonesia, 29 Juli 2019.

\section{Website}

Anonim, Hapusnya Hak Tanggungan/Roya: https://www.atrbpn.go.id/Publikasi/ StandarProsedur/moduleId/122856/itemName/Roya/controller/Item/action/ Detail, (Diakses pada tanggal 06 Agustus 2019).

Sinaga, Herianto, Tanggung Jawab Werda Notaris terhadap Akta yang Dibuatnya, https://media.neliti.com/media/publications/14062-ID-tanggungjawab-werdanotaris-terhadap-akta-yang-dibuatnya.pdf, (Diakses pada tanggal 05 Desember 2019). 